\section{PÉNZÜGYI TUDATOSSÁG FEJLESZTÉSE AZ ÖNGONDOSKODÁSI SZEMLÉLET ERŐSÍTÉSÉÉRT}

Németh-Lékó Adrienn ( vezetö-kormányfốtanácsos, Pénzügyminisztérium ), adrienn.nemeth-leko@pm.gov.hu

\section{ÖSSZEFOGLALÓ}

A pénzügyi tudatosság fejlesztése, az öngondoskodási szemlélet erősítése közös érdekünk és célkitűzésünk: a tudatos pénzügyi döntések hosszú távon hozzájárulnak a gazdaság és a versenyképesség növekedéséhez, valamint a pénzügyi intézményrendszer, biztositási szektor fejlödéséhez, stabilitásához is. A pénzügyi tudatosság fejlesztése időigényes folyamat, amelynek eredményei hosszú távon jelentkezhetnek. A végső cél, hogy a pénzügyi tudatosság a mindennapok részévé váljon, és az emberek megfontoltan döntsenek az előtakarékoskodásról, befektetésekről, biztosításokról. Jelen írás bemutatja a pénzügyi kultúra fejlesztése terén eddig megtett kormányzati lépéseket, és vázolja a jövőbeni prioritásokat.

\section{SUMMARY}

Improving financial awareness, strengthening the self-care approach is our common interest and objective: in the long term, conscious financial decisions also contribute to economic growth and competitiveness, as well as to the development and stability of the financial institutions and insurance sector. The development of financial awareness is a time-consuming process, the results of which may arise over the long term. The ultimate goal is to make financial awareness a part of everyday life and to make informed choices about saving, investment and insurance. This article presents the steps taken so far by the Government in improving financial literacy and outlines future priorities.

Kulcsszavak: pénzügyi tudatosság Key words: financial awareness

JEL: G5

DOI: $10.18530 /$ BK.2020.3-4.90

http://dx.doi.org/10.18530/BK.2020.3-4.90

\section{Előzmények}

A pénzügyi kultúra fogalma és a lakosság pénzügyi ismereteinek fejlesztésére vonatkozó igény már a XX. század elején megjelent az angolszász országokban azzal a céllal, hogy megteremtsék a pénzügyi termékek iránti keresletet, továbbá mérsékeljék az egyének nem megfelelő pénzügyi döntéseiből adódó kockázatokat. Magyarországon viszont csak a 2008-as pénzügyi válságot követően került előtérbe a téma: a devizaalapú hitelezés következményeinek kezelése rávilágított a lakosság pénzügyi ismereteinek alapvető hiányosságaira és az ebből adódó mikro- és makrogazdasági szintű kockázatokra. Emellett a Pénzügyminisztérium Ügyfélszolgálatára beérkező panaszos levelek is azt támasztják alá, hogy a magyar lakosság pénzügyi tudása, magatartása és attitüdje korántsem megfelelő. Jellemző a körültekintést és a kockázatok felmérését nélkülöző, impulzív pénzügyi döntések meghozatala, az esetleges kedvezőtlen pénzügyi következmények esetén pedig elvárás - sok esetben jogosan - a pénzügyi szolgáltatókra vonatkozó elöírások szigorítása, a fogyasztóvédelmi szabályok további erősítése és végső soron az egyén felelőssége helyett „az állam” helytállása.

A lakosság nem megfelelő pénzügyi tudatosságára vonatkozó empirikus következtetéseket a nemzetközi és hazai kutatási eredmények is megerősítik.

Az eltérő módszertanból adódóan az egyes felmérések eredményei meglehetősen nagy szórást mutatnak, mindazonáltal az alapvető trendek egyértelműen kirajzolódnak.

A felnőtt lakosság pénzügyi tudatosságának nemzetközi összehasonlító kutatását a Gazdasági és Együttműködési Fejlesztési Szervezet (OECD) koordinálja. Mind a 2015-ös ${ }^{1}$, mind a 2020-as² OECD módszertan szerinti felmérés azt mutatja, hogy míg a pénzügyi ismeretek tekintetében a magyar lakosság más országokhoz képest nincs komoly lemaradásban, addig a pénzügyekhez való hozzáállás és a tényleges magatartás szempontjából átlagon alul teljesítünk, különösen a tudatos tervezés és a pénzügyek nyomon követése, valamint a megtakarítási hajlandóság tekintetében. A tudatos tervezés legalapvetőbb formáját képező háztartási költségvetést csak minden ötödik ember (21\%) készít Magyarországon, ráadásul az arány csökkenő trendet mutat a 2010-es (32\%) és a 2015-ös (25\%) adatokkal összehasonlítva. A megtakarítási hajlandóság vonatkozásában is jelentős a lemaradásunk a nemzetközi átlagtól (70\%), pozitív változás azonban, hogy a megtakarítással rendelkezők aránya 2015 óta közel a duplájára emelkedett (27\%-ról 51\%-ra, amint az 1. ábra mutatja). ${ }^{3}$ 
1. ábra: Megtakarítási tevékenységek

Megtakarítási tevékenységek

elmúlt 12 hónapban, százalék, Bázis: TOTÁL, N=10001

Bármiféle megtakarítási tevékenység

Részvénybe fektetett be

Megtakarítása volt pl. fogyasztói csoport keretében

Kötvényt vásárolt vagy befektetési alapba fektetett be

Egyéb megtakaritással (ideértve az arany vagy$$
\text { ingatlan, mütárgy) }
$$

Családjának adta a pénzt, hogy megőrizzék

Megtakarítási számlán helyezte el a pénzét

Megtakarított pénzét otthon tartotta vagy magáná hordt

QF3: Az elmúlt 12 hónapban rendelkezett-e Ön [személyesen] a következök közül bármelyik megtakaritással, függetlenül attól, hogy a pénz most is megvan-e?

Forrás: A lakosság pénzügyi kultúrája 2018, Kutatási Jelentés a Pénziránytü Alapitvány részére

A Központi Statisztikai Hivatal (KSH) 2018. IV. negyedévben, illetve 2019. I-IV. negyedévekben a szokásos évi Háztartási költségvetésiéséletkörülmény naplóvezetésesfelvétele (HKÉF) keretében tett fel pénzügyi tudatosságot mérő kérdéseket. Összehasonlítva az OECD módszertanon alapuló kutatások eredményével, a KSH-felmérés kedvezőbb képet mutat a tudatos pénzügyi tervezés vonatkozásában (eltérő gyakorisággal ugyan, de a háztartások 52-56\%-a készít költségvetést). A befektetéssel és/vagy valamilyen megtakaritással rendelkezők aránya (35-39\%), illetve pénzügyi termék választásakor az ajánlatokat összehasonlító tudatos fogyasztók aránya (30-38\%) azonban továbbra is elmarad a nemzetközi átlagtól. A háztartások pénzügyi stressztürő képességére vonatkozó kérdésekre adott válaszok alapján a háztartások több mint fele (51-61\%) nem lenne képes egyhavi jövedelmének megfelelö kiadás önerőből történő finanszírozására, valamint a háztartás főjövedelemforrásának kiesése esetén mindössze a háztartások ötöde lenne képes több mint három hónapig fedezni a megélhetési költségeit. Ezek a számok békeidőben is a lakosság nagyfokú sebezhetơségét mutaták, a jelenlegi járványhelyzetben pedig különösen aggályosak.

A Pénztárszövetség megbízásából készitett 2019. évi nyugdijtudatossági felmérés ${ }^{4}$ eredménye is alátámasztja az öngondoskodási szemléletben mutatkozó hiányosságokat. A nyugdíj mint megtakarítási cél továbbra is háttérbe szorul az egyéb megtakarítási célokkal szemben (elöre nem látható helyzetek, lakáscél, egészségügyi kiadások, gyermekek tanulmányainak finanszírozása). A felmérés alapján 10-ből 4 embernek nincs semmiféle nyugdij-megtakarítása. Az emberek többsége (63\%) az állami nyugdíjból tervezi nyugdíjas éveit finanszírozni, minden második ember (51\%) nyugdíjasként is tovább dolgozna, míg kifejezett nyugdíj-megtakarítással csupán minden harmadik ember rendelkezik. Ingatlan bérbeadásából származó jövedelemmel 15, gyerekek segítségével pedig 11 százalék tervezi kiegészíteni az állami nyugdíjat. A megtakarítással rendelkezők megtakarításain belül továbbra is elsőbbséget élvez a bankszámla és a készpénz (33\%), a kifejezetten nyugdíjcélú megtakarítási formák aránya pedig alacsonynak tekinthető (önkéntes nyugdíppénztári tagsággal 22\%, nyugdíjbiztosítással 9\%, nyugdij-előtakarékossági számlával $11 \%$ rendelkezik).

A nyugdíj mint megtakarítási cél továbbra is háttérbe szorul az egyẻb megtakaritási célokkal szemben.

Mindamellett a pénzügyi piacokon olyan bonyolult, összetett termékek jelentek meg az utóbbi években, amelyek megértése, igénybevétele még az alapvető pénzügyi ismeretekkel és jártassággal rendelkező egyének számára is kihívást jelent.

Az ügyfelek védelme érdekében a jogalkotó reagált erre a kihívásra ${ }^{5}$ - nagyobb felelösséget téve a pénzügyi szolgáltatókra -, pusztán szabályozói lépésekkel azonban nem kezelhető a probléma. Mindaddig, amíg nem vállal valaki nagyobb kockázatot, mint amennyi belátható számára, nem probléma, ha nem ismeri az összes pénzügyi terméket, ami elérhető a pénzügyi piacon. ${ }^{6}$ A magasabb életszínvonal és az anyagi biztonság iránti elvárás, illetve a fogyasztói társadalom támasztotta igények kielégitése azonban gyakran azt eredményezi, hogy a magasabb hozamok elérése érdekében olyan pénzügyi termékeket is igénybe vesznek az emberek, amelyek tényleges mechanizmusát és kockázatait nem képesek felmérni. A biztositási területen a kötelező tanácsadás, illetve az alkalmassági tesztek ugyan éppen arra irányulnak, hogy ilyen termék megvásárlása ne fordulhasson elö, és egy megfelelően végigvitt tanácsadási folyamat segít abban, hogy az ügyfél tisztában legyen a saját céljaival, a hozzá rendelhető időtávokkal és azzal, hogy milyen pénzügyi eszközök közül választhat. Mindazonáltal a pénzügyi termékek innovációja és a lakosság pénzügyi ismeretei közötti rés folyamatosan növekszik, sőt a fintech megoldások megjelenésével ez a folyamat még inkább felgyorsul. Ez pedig kockázatot jelent nemcsak a fogyasztók, hanem a pénzügyi szolgáltatók és a pénzügyi stabilitás szempontjából is.

\section{A lakosság pénzügyi tudatosságának fejlesztése érdekében tett lépések}

A lakosság pénzügyi tudatosságának fejlesztése érdekében számos kezdeményezés indult a közelmúltban. Az MNB mellett - amely a pénzügyi stabilitásért való felelőssége és a pénzügyi fogyasztóvédelmi feladata alapján jelentős szerepet vállalt a pénzügyi tudatosság kialakításában és terjesztésében - kereskedelmi bankok, a pénzügyi ágazat érdekképviseleti szervei és civil szervezetek is indítottak edukációs programokat. Egyértelművé vált azonban, hogy a lakosság pénzügyi tudatosságának fejlesztésében érdemi eredményt csak úgy lehet elérni, ha ezeket a széttöredezetten működő és hatásaiban elaprózott programokat összehangoltan, 
egységes keretbe foglaltan valósítjuk meg. Ezzel a céllal fogadta el 2017-ben a Kormány a lakosság pénzügyi tudatosságát fejlesztő stratégiát.?

\section{Mit is akarunk fejleszteni?}

A stratégia megalkotásának kiindulópontja a pénzügyi tudatosság fogalmának meghatározása volt. A nemzetközi szakirodalomban ugyanis nincs egységes definíció, de még következetesen használt megnevezés sem (financial awareness, literacy, culture, comptence stb). Az elörelépés mérhetősége és nemzetköziösszehasonlíthatósága érdekében az OECD meghatározását tekintjük irányadónak. ${ }^{8}$ Ez alapján a pénzügyi tudatosság bizonyos szintű pénzügyi kultúrát (ismereteket, készségeket), célirányos magatartást, valamint megfelelő hozzáállást (attitűdöt) feltételez. Pénzügyi ismeretek alatt a lényeges pénzügyi fogalmak (infláció, kamatos kamat, járadék, hitel-kölcsön, biztosítás stb.), a pénzügyi termékek és szolgáltatások ismeretét és egyéb praktikus tudnivalókat (pl. átutalási megbízás, bankkártyaadatok védelme stb.) kell érteni. A készség (pl. a számolás és a szövegértés) az a megtanult ismeret, amit a cselekvés és a tevékenység során közvetlen tudati ellenőrzés nélkül használunk. A pénzügyi magatartás körébe sorolható a családi költségvetés készítése, a hosszú távú tervezés (felkészülés nyugdíjra, betegségre stb.), a takarékoskodás, a pénzügyi döntéshozatal (képes választani, és megfelelő időben cselekedni), a tájékozódás és a tanácsadó igénybevétele is. A hozzáállás, vagyis az attitüd a személy pénzügyekhez való viszonyát, tartós beállítódását jelenti, például a jövőhöz viszonyulást, az öngondoskodást, a megfontoltságot, az eredményközpontúságot.

A Kormány által elfogadott stratégia az optimális pénzügyi döntések meghozatalához szükséges pénzügyi ismeretek megszerzésére, a tudatos és körültekintő pénzügyi magatartás megalapozására, valamint a hosszú távú gondolkodás szemléletének kialakítására is kiemelt hangsúlyt fektet, és ennek megfelelően határozta meg a célkitűzéseket.

\section{A lakosság pénzügyi tudatosságának fejlesztését célzó stratégia célkitüzései}

1. A köznevelés rendszerén belüli valós pénzügyi edukáció lehetőségeinek megteremtése, erősítése és általánossá tétele.

2. A tudatos pénzügyi magatartás alapjainak megteremtése és a háztartások pénzügyi stressztűrő képességének erősítése.

3. Körültekintő pénzügyi döntéseket elömozdító szemlélet megteremtése és a tudatos pénzügyi fogyasztói magatartást támogató intézmények/ infrastruktúrák létrehozása, széles körü megismertetése.

4. A lakosság öngondoskodási szemléletének erősítése.

5. A pénzügyi termékekhez, pénzügyi alapszolgáltatásokhoz való hozzáférés és pénzügyi beilleszkedés (financial inclusion) mértékének számottevő növelése.

6. A korszerű, készpénzkímélő fizetési eszközök használatának ösztönzése, a készpénzhasználat súlyának csökkentése.

7. A körültekintő hitelfelvétel támogatása.
A stratégia hétéves időszakot ölel fel 2017-2023 között, végrehajtására kétéves, egymásra épülő, gördülő cselekvési tervekben kerül sor. Az elérendő cél a lakosság meggyőzése arról, hogy foglalkozzanak felelösen a pénzügyeikkel: készítsenek költségvetési, háztartás-gazdálkodási tervet, törődjenek megtakarításaikkal és az öngondoskodással, legyenek hosszú távú pénzügyi céljaik, valamint ne idegenkedjenek a pénzügyektől, hanem frissítsék ismereteiket, ezáltal magabiztosabbá és tájékozottabbá váljanak a pénzügyi döntések területén, és elönyösebb döntéseket hozzanak, amelyek meghozatalában támaszkodjanak a szolgáltatás- és termékválasztó platformok használatára is.

\section{A munkában a Pénzügyminisztérium egyfajta ernyőszerepet tölt be.}

Ebben a munkában a Pénzügyminisztérium egyfajta ernyőszerepet tölt be: koordinálja és katalizálja a pénzügyi tudatosság fejlesztésében aktív szervezetek tevékenységét, továbbá ösztönzi az új szereplők belépését.

\section{A stratégia első szakasza a köznevelés rendszerén belüli valós pénzügyi edukáció meg-} teremtésére fókuszált.

Az első célkitűzés kiemelt kezelését az indokolta, hogy az általános pénzügyi kultúrát gyermekkorban kell megalapozni, az iskolai pénzügyi képzés garantálhatja, hogy a következő nemzedék a gyakorlati életben használható pénzügyi ismeretekre és készségekre tegyen szert. Figyelembe kell venni továbbá, hogy a fiatalok a legfogékonyabbak az új impulzusok befogadására és a köznevelés rendszerén keresztül a legkönnyebben elérhető célcsoportot is ők alkotják egyúttal. Ezen túlmenően a diákokon keresztül közvetetten az őket képző pedagógusok, valamint a szülők és a nagyszülők elérése is lehetővé válik, így a ténylegesen megszólított célcsoport szélesebb, mint a szűken definiált diákok köre. Ez utóbbi különösen fontos szempont egy olyan társadalomban, ahol a felnőttek jelentős része gyakorlatilag semmilyen pénzügyi képzésben nem részesült, és egy olyan rendszerben nőtt fel, amely nem támogatta az öngondoskodási szemlélet, az egyéni felelősségvállalás kultúrájának kialakulását. Ebből adódóan sok családban nem is tudnak követendő példát mutatni a mai fiataloknak, és a családi minták hiányában az oktatási rendszernek kellene a lexikális ismeretek átadásán túl a szemléletformálás kihívásának is eleget tennie. Ideális esetben a pénzügyekhez való megfelelő attitűdöt a családon belül sajátítják el a gyerekek, de a múltbeli hiányosságok miatt fordított irányú szemléletformálásra is szükség lenne, amely a gyerekek irányából hat a szülőkre, nagyszülőkre. A fiatalok pénzügyi tudatosításának prioritásként történő kezelése abból a szempontból is indokolt továbbá, hogy az iskolapadból kikerülő diákok nagyon rövid időn belül számos olyan döntési helyzettel szembesülnek, amelyek pénzügyi hatása hosszú távon meghatározza boldogulásukat (továbbtanulás, diákhitel, első munkahely, lakhatás, családalapítás stb.). 
A fiatalok pénzügyi tudatosságának fejlesztését célzó intézkedések priorizálásakor az elsődleges szempont a minél nagyobb szinergia elérése volt. Ez a megközelítés lehetővé tette, hogy az erőforrások ne aprózódjanak el, és megbízható alapra lehessen építeni a következő évek kezdeményezéseit. A korábbi évek sikeres programjainak folytatása mellett a cél a minél nagyobb elérés volt - legyen szó a tanórán kívüli programokkal megszólított diákok számáról, a szakirányú továbbképzésben részt vevő pedagógusok számáról vagy az oktatási intézményekhez eljuttatott tankönyvek, oktatási anyagok példányszámáról. Az, hogy a 2020. évi PÉNZ7 témahéten ${ }^{9}$ több mint 1200 iskola 217 ezer diákja vett részt több mint 900 önkéntes közreműködésével; a Pénziránytű Alapítvány ingyenes képzésein 2019 végéig több mint 2400 pedagógus vált szakmailag és módszertanilag is felkészültebbé; a Pénziránytű Alapítvány akkreditált tankönyvei, kiadványai pedig több mint 400 ezer diákhoz jutottak el, egyértelműen jelzi ezeknek a programoknak a sikerét. Egy-egy rendhagyó tanórán való részvétel vagy egy pénzügyi teszt kitöltése természetesen még nem jelenti azt, hogy a diákok tudnak bánni a pénzügyekkel. Egyértelmű eredménye azonban ezeknek a programoknak, hogy sikerült az iskolákba bevinni a pénzügyi tudatosság témáját, és a magas szakmai színvonalon és a fiatalok igényei alapján előkészített tanári segédletek, tanmenetek segítenek fokozatosan lebontani a nem gazdasági-pénzügyes szakos pedagógusok pénzügyek oktatásával szembeni tartózkodását

\section{Széles körủ szakmai együttmüködés a fiatalok pénzügyi tudatosságának fejlesztéséért}

A szakmai partnerek által megvalósított, fiatalok pénzügyi edukációját célzó programok felsorolásszerű bemutatása is meghaladná jelen cikk terjedelmi korlátait, ezekről részletes információ a Pénzügyminisztérium által elindított www.okosanapenzzel.hu honlapon található. Itt többek között beszámolunk a pénzügyi tudatosság témájú versenyekről, tematikus táborokról, valamint a honlapról is elérhetőek a szakmai partnerek által kifejlesztett pénzügyi témájú játékok, applikációk, képregények és kisfilmek.

A teljesség igénye nélkül a biztosítási területen kiemelendő program a Biztonság Hete, amelyet a MABISZ, valamint a föváros és országos rendőri szervek kezdeményezésére 2017-től rendeznek meg országos lefedettséggel, kapcsolódva a biztosítási világnaphoz, valamint a nemzetközi EDWARD Day-hez (European Day Without A Road Death Európai Nap Közúti Áldozat Nélkül). A Biztonság Hete rendezvényein látványos bemutatókkal és előadásokkal több ezer tanuló figyelmét hívják fel a biztosítások szerepére és fontosságára, valamint a mindennapi kockázatokra, veszélyekre, azok helyes kezelésére. A 2020. évi PÉNZ7 egyik kiemelt pénzügyi témája is a biztosítás volt, és a rendkívüli tanórák keretében 133 ezer diák szerzett ismereteket a biztosításokról több mint 350, a biztosítási szakmából érkező önkéntes közreműködésével. Az idén már második alkalommal megrendezett Nagy Diák Pénzügyes Teszt szervezésébe is bekapcsolódott a MABISZ, és a játékos, szórakoztató és egyúttal edukatív teszt mintegy 16 ezer online kitöltője, illetve a Pénzügyminisztériumban megszervezett elődöntő és döntő résztvevői a biztosítási területen is tesztelhették tudásukat. A fiatalabb korosztályt célozza meg a biztosításokról játékos formában szóló, érzékenyítő képregénysorozat, amely az alapvető biztosítási, baleset-megelőzési ismeretek 9-14 éves korosztály számára való átadását hivatott megkönnyíteni a MABISZ honlapján.

\section{A megújult Nemzeti Alaptanterv további pozitív elmozdulást hozhat}

Amint az Állami Számvevőszék (ÁSZ) kutatása ${ }^{10}$ is rámutatott, a rövid (1-2 órás) képzések, amelyek ráadásul jellemzően több témát is átfognak, nem biztosítják a pénzügyi ismeretek eredményes átadását. Ebből a szempontból pozitív elmozdulást hozhat a 2020. januárban elfogadott Nemzeti Alaptanterv (Nat.), amely megteremti a köznevelés rendszerén belül a diákok pénzügyi tudatosításának intézményi kereteit. A kerettantervek alapján a pénzügyi ismeretek oktatása, a pénzügyi tudatosság fejlesztése több tantárgy (matematika, történelem és állampolgári ismeretek, földrajz, technika) tematikájában is megjelenik. A teljes képhez azonban hozzátartozik, hogy a pénzügyi ismeretek önálló tantárgyként nem jelenik meg (a szakgimnáziumok kivételével), és csak a szabadon tervezhető órakeret terhére építhető be a helyi tantervekbe. Ezenkívül az új Nat. az 1., 5. és 9. évfolyamon kerül bevezetésre felmenő rendszerben, így a diákok teljes körét lefedő pénzügyi edukáció megvalósítása csak többéves időeltolódással valósul meg. Ennek megfelelően a jövőben is indokolt az első kétéves cselekvési terv sikeres tanórán kívüli programjainak folytatása. Hosszabb távon elérendő cél pedig, hogy a pénzügyi ismeretek oktatása kötelező tantárgyként szerepeljen a tantervben.

\section{Hosszabb távon elérendő cél pedig, hogy a pénzügyi ismeretek} oktatása kötelező tantárgyként szerepeljen a tantervben.

Annak érdekében, hogy a megújult Nat. bevezetése gyakorlati eredményeket is hozzon a fiatalok pénzügyi kompetenciáinak fejlesztésében, elengedhetetlen a pedagógusképzés és szakirányú továbbképzés erősítése. Emellett rövid távon a gazdasági-pénzügyi felsőoktatásban részt vevő hallgatók bevonása nyújthat támogatást a nem közgazdász szakos pedagógusoknak a pénzügyi ismeretek oktatásában. A megfelelő elméleti tudással rendelkező egyetemi hallgatók egy nyelvet beszélnek az általános és középiskolás kortársaikkal, a fiatalok számára hiteles, közérthető formában tudják átadni a felelős pénzügyi magatartáshoz szükséges alapokat. Bevonásukra az egyetemek szakmai iránymutatása és a szaktanárok pedagógia iránymutatása alapján kerülhet sor elsősorban a pénzügyi tudatosság témájú, tanórán kívüli programok megtartásában. ${ }^{11}$ Fontosnak tartjuk továbbá a fiatalok pénzügyi tudatosságának fejlesztésében kiemelkedő teljesítményt nyújtó pedagógusok, oktatási intézmények és diákok elismerését is. Az e célból a pénzügyminiszter által alapított Pénzügyi Tudatosság Fejlesztéséért Díj egyúttal a jó gyakorlatok beazonosítását és megosztását is szolgálja. Szükséges továbbá, hogy a diákok ne csak elméleti ismereteket szerezzenek, az oktatási intézmények 
a megszerzett tudás gyakorlati alkalmazására is biztosítsanak lehetőséget az iskolai élethez kapcsolódó fizetések készpénzkímélő formában történő lebonyolításának lehetővé tételével (bankkártyás fizetés az iskolai büfében, ebédbefizetés átutalással). Célunk, hogy a 2018-ban kísérleti jelleggel 15 oktatási intézményben elindult Készpénzkímélő Iskolák Programhoz minél több iskola csatlakozzon. Ezen kívül szeretnénk további területekre is kiterjeszteni az egyetemekkel történő együttmüködésünket. Reális elvárásnak tartjuk, hogy a felsőoktatásból kikerülő minden diplomás rendelkezzen a tudatos pénzügyi döntések meghozatalához szükséges pénzügyi ismeretekkel és készségekkel, ezért támogatjuk a pénzügyi kultúra választható tantárgy indítását a nem gazdasági karon tanuló hallgatók számára.

\section{A felnőtt lakosság pénzügyi tudatosságának fejlesztését sem hanyagolhatjuk e}

Annak érdekében, hogy a lakosság pénzügyi tudatosságában mérhető elmozdulást érjünk el, a következő cselekvési terv időhorizontján a felnőttek és különös tekintettel a sérülékeny csoportok (munkanélküliek, alacsony jövedelemmel rendelkezők) képzésére is hangsúlyt kell fektetni. Elérendő cél a lakosság stressztürő képességének és megtakarítási hajlandóságának a növelése, valamint a körültekintő termék- és szolgáltatásválasztás általánossá tétele. E tekintetben vannak évek óta jól működő programok (MNB Pénzügyi Tanácsadói Irodahálózatának független tanácsadói szolgáltatása, MNB Pénzügyi Navigátor ismeretterjesztő anyagai) és olyan új kezdeményezések, amelyekre a következő cselekvési terv intézkedéseit építeni tudjuk. Kiemelendő ezek közül az Állami Számvevőszék megyei kormányhivatalokkal kötött együttmüködése, amelynek keretében a Számvevőszék tájékoztató anyagai, az online és közösségi médiaplatformokon elérhető animációs kisfilmjei a kormányhivatalok ügyféltereiben is elérhetőek lesznek; vagy a Pénzügyminisztérium által indított okosanapenzzel.hu weboldal, amelyen minden korosztály, közérthető formában, konkrét élethelyzetekhez rendelten is megtalálja a pénzügyi tudatossággal kapcsolatos valamennyi információt.

\section{Az állami segítségnyújtás mellett az öngondoskodás egyéni felelősségvállalást igényel} a lakosság tagjaitól

Az elmúlt években az európai uniós átlagot meghaladó mértékű gazdasági növekedés, a rekordszintű foglalkoztatás, valamint a munkát terhelő adók jelentős csökkentése a háztartások rendelkezésére álló jövedelem növekedését eredményezte. A makrogazdasági adatok azt mutatják, hogy az elkölthető jövedelemmel párhuzamosan a háztartások fogyasztása is növekedett, ugyanakkor jelentősen javultak a lakosság megtakarítási lehetőségei is, és a hazai megtakarítási ráta európai viszonylatban is kiemelkedő (a rendelkezésre álló jövedelem 12,0\%-a 2018-ban). A Kormány az adókedvezményekkel, a lakosság állampapírokba történő befektetésének ösztönzésével a lakosság öngondoskodási lehetöségeit kívánja támogatni. A Kormány intézkedéseinek köszönhetően az elmúlt időszakban a lakosság megtakarításai érdemben javultak, ugyanakkor a megtakarításokon belül a készpénzállomány aránya még mindig magas. Ezért fontos cél, hogy a lakosság egyre nagyobb arányban vegye igénybe a különböző öngondoskodási formákat. A Kormány elkötelezettségét mutatja ebben a kérdésben, hogy 2014. január 1-jétől a személyi jövedelemadóról szóló törvény adókedvezményt biztosít a nyugdijbiztosítással rendelkezők részére, csakúgy, mint az egyéb nyugdíjcélú megtakarítással rendelkezőknek. Az állami segítségnyújtás mellett azonban az öngondoskodás egyéni felelősségvállalást igényel a lakosság tagjaitól, jellemzően egyéni döntések alapján jöhet létre. Három év nyugdíjcélú megtakarításait mutatja az 1. táblázat.

1. táblázat: Nyugdíjcélú megtakarítási formák elterjedtsége

\begin{tabular}{|l|l|l|l|}
\hline & $\mathbf{2 0 1 7}$ & $\mathbf{2 0 1 8}$ & $\mathbf{2 0 1 9}$ \\
\hline Nyugdijbiztositás & & & \\
\hline Szerződésszám & 252301 & 297601 & 351111 \\
\hline Éves díbeevétel (Mrd HUF) & 57,2 & 72,7 & 87,6 \\
\hline Dijtartalék (MNB adatok alapján becsült érték, Mrd HUF) & 107 & 168 & 240 \\
\hline Önkéntes nyugdíjpénztárak & & & \\
\hline Taglétszám & 1138076 & 1134172 & 1110842 \\
\hline $\begin{array}{l}\text { Azonosított egyéni számlán jóváírt tagdíbevétel } \\
\text { (Mrd HUF) }\end{array}$ & 100,9 & 112,5 & 104,3 \\
\hline Portfólió piaci értéken (Mrd HUF) & 1392,0 & 1403,3 & 1526,9 \\
\hline Nyugdij-elötakarékossági számla (NYESZ) & & & \\
\hline Vezetett NYESZ értékpapírszámlák száma & 121393 & 113131 & 104682 \\
\hline $\begin{array}{l}\text { NYESZ számlákon nyilvántartott értékpapír-állomány } \\
\text { piaci értéken (Mrd HUF) }\end{array}$ & 494,5 & 469,3 & 466,5 \\
\hline
\end{tabular}

Forrás: $M N B$

Megjegyzés: A nyugdíjcélú öngondoskodás negyedik formájának, a foglalkoztató nyugdíjszolgáltató intézményeknek a szerepe elhanyagolható a hazai kiegészitö nyugdíjpiacon.

\section{Időigényes folyamat kezdetén járunk}

A pénzügyi tudatosság fejlesztése, a pénzügyi magatartás és a pénzügyekhez füződő attitűd megváltoztatása időigényes folyamat, amely túlmutat nemcsak a kétéves cselekvési terv, de a hétéves stratégia időhorizontján is. Az elméleti pénzügyi ismeretek átadásában már rövid távon is lehet eredményeket elérni, a pénzügyi magatartás és hozzáállás érdemi megváltoztatásához azonban egy pénzügyileg tudatos generáció felnevelése és az Y generáció megszólítása (Kovács, 2018) szükséges, és ez különösen igaz az öngondoskodási szemlélet vonatkozásában. 
A jelenlegi járványügyi helyzet azonban gyökeresen változtatja meg a mindennapjainkat, és a megtakarításokhoz, digitalizációhoz való hozzáállásunkra is hatással lehet. Várakozásaink szerint a COVID-19 kedvező elmozdulást hoz a tudatos pénzügyi tervezésben és a készpénzkímélő fizetési eszközök használatában. A 2008-as pénzügyi válságot követően megjelent longitudinális kutatások azt mutatták, hogy a válság hatására a pénzügyi tudatosság szignifikánsan javult, időben távolodva azonban a válságot jelentő évektől beindul a felejtés. ${ }^{12} \mathrm{~A}$ jelenlegi helyzetben az elöttünk álló kihívás az, hogy a COVID-19 jelentette nehézségekből előnyt kovácsoljunk, és a pozitív irányú folyamatokat hosszú távon fenn tudjuk tartani.

\section{HIVATKOZASOK}

'https://www.oecd.org/daf/fin/financial-education/OECD-INFE-International-Survey-of-Adult-Financial-Literacy-Competencies.pdf Letöltve: 2020.04.17.

2https://www.oecd.org/financial/education/oecd-infe-2020-international-survey-of-adult-financial-literacy.pd

A 2020 nyarán publikált nemzetközi kutatási eredmények 26 országból összesen 125 ezer 18-79 év közötti felnőtt válaszain alaPunat. GfK Hungária Piackutató Kft)

OECD modszertan szerinti mérések kétségtelen előnye az eredmények nemzetközi összehasonlíthatósága, mindazonáltal ezeket az eredményeket makrogazdasági kontextusban célszerủ értékelni, különösen a megtakaritással rendelkezők arányát tekintve. A magasabb egy fö́re jutó GDP-vel rendelkező országokban az egyének rendelkezésére állójövedelem növekedésével párhuzamosan csökken az alapvető fogyasztási javak megszerzésére fordított jövedelem aránya, és nö a potenciális megtakaritási képesség. ${ }^{4} \mathrm{Az}$ ÖPOSZ reprezentatív kutatásának eredményei (2019.)

https://www.youtube.com/watch?v=_pkggYVjdiQ\&feature=youtu.be Letöltve: 2020.04.17

Lásd a biztositási êrtekesitessrôl szolo europai uniós iranyelv, valamint a lakossagi befektetési csomagtermékekre és biztositasi alapú befektetési termékekre vonatkozo európai unios rendelet hazai jogba tortenonóátültetése; továbbá az MNB, a Magyar Biztositók Szövetsége (MABIZ) és a Pénzügyminisztérium együttmüködésének eredményeként kialakitott etikus életbiztositás szabályozási rendszer.

${ }^{6} \mathrm{~A}$ 2019. májusban a Pénzügyminisztériumban tartott pénzügyi tudatosság konferencia kerekasztal-beszélgetésén elhangzott megállapitás Béres Dániel részéről.

A lakosság penzzugyi tudatosságát fejlesztő stratégia elfogadásáról szóló 1919/2017. (XI.8.) Korm. határoza

(A) edge, skill, attitude and behaviour necessary to make sound financial decisions and ultimately PÉNZ7 tém hót: Magyarorźng 2015-bencs

势

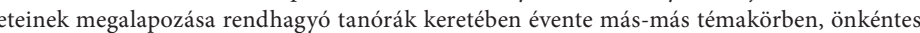
pénzügyi szakemberek részvételével.

${ }^{10}$ Pénzzügyi kultúra fejlesztési programok felmérése, 2016

https://asz_hu/storage/files/files/Publikaciok/Elemzesek_tanulmanyok/2016/penzugyi_kult_fej__programok.pdf?download=true Letöltve: 2020.04.17

"A Pénzügyminisztérium és négy felsőoktatási intézmény által megkötött együttmüködési megállapodás alapján a közelïvő̋ben várható a kortárs mentor program elinditása, de pozitív gyakorlati tapasztalatok már jelenleg is vannak: a MABISZ megbizásából

például egyetemista fiatalok tartanak órákat biztosittási ismeretekrỏl középiskolásoknak.
"2Dr. Prof Németh Erzsébet - Béres Dániel PhD - Zsótér Boglárka PhD. (2019.): A társadalmi, gazdasági környezet változásainak hatása a pénzügyi kultúrára az OECD 2010, 2015 és 2018 hazai pénzügyi kultúra felmérései alapján

\section{IRODALOMJEGYZÉK}

A lakosság pénzügyi tudatosságát fejlesztó stratégia elfogadásáról szóló 1919/2017. (XII.8.) Korm. határozat

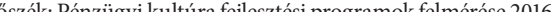

https://www_aszhw/storage/files/files/Publikaciok/Elemzesek_tanulmanyok/2016/penzugyi_kult_fejl_programok pdf?download=true Letöltve: 2020.04 .17 .

Dr. Prof Németh Erzsébet - Béres Dániel PhD - Zsótér Boglárka PhD. (2019.): A társadalmi, gazdasági környezet változásainak hatása a pénzügyi kulturarara $\mathrm{az} \mathrm{OECD} 2010,2015$ és 2018 hazai pénzügyi kultúra felmérései alapjàn

FTORK ON FINANCIAL LITERACY FOR htps://www.oecd.org/daf//in/financial-education/OECD-INFE-International-Survey-of-Adult-Financial-Literacy-Competencies.pdf Letöltve: 2020.04.17.

OLCD/INFE 2020 International Survey of Adult Fnancial Literacy

https://www.oecd.org/financial/education/oecd-infe-2020-international-survey-of-adult-financial-literacy.pdf Letöltve: 2020.04.17.

列 